\title{
Preoperative headache in patients submitted to unrupted brain aneurysm clamping
}

\author{
Cefaleia pré-operatória em pacientes submetidos a pinçamento de aneurisma cerebral não roto
}

Míriam Geisa Virgens Menezes ${ }^{1}$, Caíque Jordan Nunes Ribeiro ${ }^{1}$, Lidiane Souza Lima ${ }^{1}$, Amanda Santos de Oliveira1 ${ }^{1}$, Mariangela da Silva Nunes $^{1}$, Maria do Carmo de Oliveira Ribeiro ${ }^{1}$

DOI 10.5935/1806-0013.20160007

\section{ABSTRACT}

BACKGROUND AND OBJECTIVES: Headache is a major symptom referred by patients with brain aneurysm. As other types of pain, it is often ignored by the multiprofessional team. Although important, headache evaluation in the preoperative period of brain aneurysm clamping is a challenge for the health team. This study aimed at evaluating preoperative headache of patients submitted to unrupted aneurysm clamping.

METHODS: This is a descriptive, exploratory and quantitative study carried out between September 2014 and May 2015 in the neurosurgery sector and the intensive care unit of a mediumsized hospital. Sample was made up of 28 patients in the preoperative period of elective craniotomy to treat unrupted brain aneurysm. Mann-Whitney, Kruskal-Wallis and Fisher Exact tests were used with significance level of $5 \%$.

RESULTS: It was observed that $78.6 \%$ of patients were females with mean age of 46.7 years. Moderate pulsing and frontal headache was the most prevalent pain. Nausea and vomiting were also present, as well as pain in the eye. Pain has worsened with physical effort and shaking the head. There has been statistically significant difference for the variables pain recurrence and pain in the eye.

CONCLUSION: This article clarifies major items to be investigated to evaluate headache of brain aneurysm patients and its characteristics to help early diagnosis and better neurologic recovery.

Keywords: Analgesia, Aneurysm, Headache, Pain, Pain measurement.

\footnotetext{
1. Universidade Federal de Sergipe. Aracajú, SE, Brasil.

Sumbitted in August 27, 2015.

Accepted for publication in January 22, 2016.

Conflict of interests: none - Sponsoring sources: none.

Correspondence to:

Maria do Carmo de Oliveira Ribeiro

Av. Cláudio Batista, S/N - Bairro Sanatório

49060-108 Aracaju, SE, Brasil.

E-mail: enffer2@gmail.com

(C) Sociedade Brasileira para o Estudo da Dor
}

\section{RESUMO}

JUSTIFICATIVA E OBJETIVOS: A cefaleia é um dos principais sintomas referidos por pacientes com aneurisma cerebral. Como outras dores são, frequentemente, ignoradas pela equipe multiprofissional. Apesar de importante, a avaliaçáo da cefaleia no pré-operatório de pinçamento de aneurisma cerebral é um desafio para a equipe de saúde. O objetivo deste estudo foi avaliar a cefaleia pré-operatória em pacientes submetidos a pinçamento de aneurisma não roto.

MÉTODOS: Estudo descritivo, exploratório, de abordagem quantitativa, realizado entre setembro de 2014 e maio de 2015 no setor de neurocirurgia e na unidade de terapia intensiva de um hospital de médio porte. A casuística foi constituída por 28 pacientes no pré-operatório de craniotomia eletiva para o tratamento de aneurisma cerebral nâo roto. Utilizaram-se os testes de Mann-Whitney, Kruskal-Wallis e Exato de Fisher e adotou-se nível de significância de 5\%.

RESULTADOS: Demonstrou-se que 78,6\% dos pacientes eram do gênero feminino com média de idade de 46,7 anos. A cefaleia pulsátil de localizaçáo frontal e intensidade moderada foi a dor mais prevalente. Náuseas e vômitos também estiveram presentes, assim como a dor no globo ocular. A dor piorou com o esforço físico e balanceio da cabeça. Houve diferença estatisticamente significativa para as variáveis: recorrência da dor e dor em globo ocular.

CONCLUSÁO: Este estudo esclarece os principais itens a serem investigados na avaliação da cefaleia do paciente com aneurisma cerebral e suas características a fim de facilitar o diagnóstico precoce e a melhora antecipada na recuperação neurológica.

Descritores: Analgesia, Aneurisma, Cefaleia, Dor, Mensuração da Dor.

\section{INTRODUCTION}

Brain aneurysms (BA) are common and affect from 3 to $6 \%$ of world population above 30 years of age ${ }^{1}$. Severe headache is a major symptom referred by BA patients ${ }^{2,3}$, especially with unrupted $\mathrm{BA}^{4}$. As other types of pain, this is a sensory, individual and untransferable experience often ignored by the health team. The reason for headaches has not yet been consistently explained, but it is believed that a possible mechanism is related to vascular distention caused by malformation in the walls of vessels involved with $\mathrm{BAs}^{5}$. 
Factors such as anxiety and depression may interfere with the frequency and intensity of acute headache in the preoperative period of unrupted BA clamping. There are evidences that this pain significantly improves after surgical treatment. However, the mechanism for such improvement is not yet clear ${ }^{4}$.

Due to major negative repercussions of headache on the life of a person, adequate evaluation and management of this pain are critical for early clinical recovery ${ }^{6}$.

Notwithstanding its importance, headache evaluation in the preoperative period of unrupted BA is still a challenge for the health team and has to be better studied to establish adequate therapy, enhance neurological recovery and decrease patients' distress.

In light of the above, this study aimed at evaluating preoperative headache in patients submitted to unrupted aneurysm clamping.

\section{METHODS}

This is a cross-sectional, descriptive, exploratory study with quantitative approach, carried out from September 2014 to May 2015, in the department of neurosurgery and the intensive care unit (ICU) of a middle-sized hospital in Aracaju, SE, Brazil.

Sampling technique was not probabilistic, by convenience and consecutive. Sample was made up of 28 BA patients. Inclusion criteria were age equal to or above 18 years, in the preoperative period of elective craniotomy to treat unrupted BA and Glasgow coma scale score equal to 15 . Data were collected by selecting medical records of patients to be submitted to elective craniotomy to treat BA. Then, documents were analyzed and data collection form was filled. Included patients were interviewed the day before surgery.

Data collection form had two parts. The first had questions about socio-demographic profile. The second part had patients' clinical data and information about pain: intensity, location and characteristics of preoperative headache, improving and worsening factors. There were also questions about analgesia. Numeric visual scale, or faces scale when patient had difficulty with the former, was used to measure pain.

Data were stored and processed by the R Core Team 2015 software. For descriptive analysis, variables were expressed in simple and percentage frequency (when categorical) or mean and standard deviation (when continuous or ordinal). Mann-Whitney test (for two independent means), Kruskal-Wallis test (three or more independent means) and Fisher Exact test (association) were used for inferential analysis. Significance level for the whole study was $5 \%$.

This study has followed recommendations of Resolution $466 / 2010$, of the National Health Council, and was approved by the Ethics Committee, Universidade Federal de Sergipe (CAAE: 32813114.8.0000.5546).

\section{RESULTS}

Participated in the study 28 BA patients. There has been predominance of females (78.6\%) and mean age was $47.6 \pm 11.2$ years. Patients' age has varied from 18 to 69 years, with higher frequency for ages above 45 years $(67.9 \%)$.

With regard to clinical variables, it was observed that $21.4 \%$ of patients had previous diagnosis of arterial hypertension $(\mathrm{AH})$ and $10.7 \%$ had $\mathrm{AH}$ associated to diabetes mellitus (DM). When asked about the reason for looking for health services, all patients have referred sudden and severe headache. In $28.0 \%$ of cases, headache was associated to syncope and in $22.0 \%$ to impaired level of consciousness (Table 1).

It has been identified that $64.3 \%$ of patients used simple analgesics at home to relieve pain. These drugs are not systematically self-administered.

Previous surgeries were reported by $46.4 \%$ of patients, of whom $30.7 \%$ had already been submitted to previous aneurysm clamping. It has to be stressed that one patient has referred being submitted to craniotomy due to brain trauma. In addition, $21.4 \%$ have reported family history of neurological surgeries (Table 1).

With regard to preoperative pain, $53.6 \%$ of patients had headache and pain intensity was moderate in $28.6 \%$ of cases. There has been prevalence of pulsing frontal headache (Table 2).

It was observed that $85.7 \%$ had pain for more than one week, lasting more than one hour in $60.4 \%$ of respondents. It should be highlighted that mean pain intensity for patients reporting having it for less than seven days was exacerbated as compared to those feeling it for a longer time. However, this difference was not statistically proven. On the other hand, in

Table 1. Clinical profile of patients in the preoperative period of aneurysm clamping. Aracaju, SE, Brazil, 2015

\begin{tabular}{lcc}
\hline Variables & $\mathrm{n}$ & $\%$ \\
\hline Comorbidities & & \\
Arterial hypertension & 6 & 21.4 \\
Diabetes mellitus and arterial hypertension & 3 & 10.7 \\
Does not have & 19 & 67.9 \\
Reason for looking for health service & & \\
$\quad$ Sudden and severe headache & 14 & 50.0 \\
Sudden and severe headache associated to syncope & 8 & 28.0 \\
Sudden and severe headache associated to & 6 & 22.0 \\
impaired level of consciousness & & \\
Previous surgery & & \\
Yes & 13 & 46.7 \\
Aneurysm clamping & 4 & 30.7 \\
Others surgeries & 9 & 69.3 \\
$\quad$ No & 15 & 53.6 \\
Relatives with similar clinical presentation & & \\
Yes & 6 & 21.4 \\
No & 22 & 78.6 \\
\hline
\end{tabular}


Table 2. Characterization of preoperative headache of patients submitted to aneurysm clamping. Aracaju, SE, Brazil, 2015

\begin{tabular}{lcc}
\hline Variables & $\mathrm{n}$ & $\%$ \\
\hline Pain intensity & 13 & 46.4 \\
No pain & 5 & 16.9 \\
Mild & 8 & 28.6 \\
Moderate & 2 & 7.1 \\
Severe & & \\
Pain location & 9 & 32.1 \\
Frontal & 5 & 17.9 \\
Temporofrontal & 4 & 14.3 \\
Frontotemporal & 10 & 35.7 \\
Others & & \\
Pain characteristics & 14 & 50.0 \\
Pulsing & 5 & 17.9 \\
Stabbing & 5 & 14.3 \\
Pressing & 4 & 17.9 \\
Others & 5 & \\
\hline
\end{tabular}

case of pain recurrence, there has been significant difference in mean pain intensity between patients referring it and denying it (Table 3).

As to headache-associated symptoms, only nausea was significant for mean pain intensity. Major factors worsening headache according to patients were physical effort and shaking of head in $46.4 \%$ and $28.6 \%$ of cases, respectively (Table 4).

Among studied neurosensory changes, pain in the eye was associated to headache (Table 5).

Data have shown that pain was managed with simple analgesics, weak opioids and non-steroid anti-inflammatory drugs (NSAIDs), being more prevalent the association among the three drugs (75\%). In $35.7 \%$ of cases, drugs were prescribed "as needed". Although pain was severe in $7.1 \%$ of patients there were no prescriptions of strong opioids.

Table 3. Association between mean headache intensity and temporal characterization of pain in patients in the preoperative period of aneurysm clamping. Aracaju, SE, Brazil, 2015

\begin{tabular}{|c|c|c|c|}
\hline Variables & $\mathrm{n}(\%)$ & $\begin{array}{l}\text { Pain intensity } \\
\text { Mean (SD) }\end{array}$ & $p$-value \\
\hline \multicolumn{4}{|c|}{ Presence of pain (days) } \\
\hline$\leq 7$ & $4(14.3)$ & $5.25(3.86)$ & $0.276^{\star \star}$ \\
\hline$>7$ & $14(85.7)$ & $0(0)$ & \\
\hline \multicolumn{4}{|c|}{ Frequency of pain (min) } \\
\hline$<60$ & $11(39.3)$ & $2.91(3.62)$ & $0.246^{\star *}$ \\
\hline$\geq 60$ & $17(60.7)$ & $2.75(3.16)$ & \\
\hline \multicolumn{4}{|c|}{ Recurrence of pain } \\
\hline Yes & $14(50)$ & $3.86(3.28)$ & $0.014^{*}$ \\
\hline No & $14(50)$ & $1.86(2.82)$ & \\
\hline
\end{tabular}

Table 4. Headache intensity and presence of other symptoms in patients in the preoperative period of aneurysm clamping. Aracaju, SE, Brazil, 2015

\begin{tabular}{lccc}
\hline Variables & $\mathrm{n}(\%)$ & $\begin{array}{c}\text { Pain intensity } \\
\text { Mean (SD) }\end{array}$ & p-value \\
\hline Pallor & $1(3.6)$ & $5(0)$ & 0.571 \\
Yes & $27(96.4)$ & $2.78(3.2)$ & \\
No & & & \\
Sweating & $6(21.4)$ & $2.67(2.66)$ & 0.978 \\
Yes & $22(78.6)$ & $2.91(3.35)$ & \\
No & & & \\
Nausea & $9(32.1)$ & $4.67(3.35)$ & 0.044 \\
Yes & $19(67.9)$ & $2(2.77)$ & \\
No & & & \\
Vomiting & $9(32.1)$ & $3.11(3.69)$ & 0.847 \\
Yes & $19(67.9)$ & $2.74(3)$ & \\
No &
\end{tabular}

Photophobia

Yes

$1(3.6)$

$9(0)$

0.062

Phonophobia

Yes

No

$1(3.6)$

$3(0)$

0.071

Sleep disorders

$$
\text { Yes }
$$

0 (35.7)

$3.6(3.17)$

0.356

No

$18(64.3)$

$2.44(3.18)$

Tearing

Yes

4 (14.3)

$3.5(3.87)$

0.681

No

$24(85.7)$

$2.75(3.12)$

Nasal obstruction

Yes

2 (7.1)

$4.5(6.36)$

0.64

No

26 (92.6)

$2.73(3)$

Postural vertigo

Yes

6 (21.4)

2 (2.76)

0.566

Pain worsens with

Neck movement
Physical effort
Shaking of head
None

1 (3.6)

5 (0)

$0.492^{\star \star}$

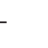


Table 5. Association of neurosensory changes and headache in patients in the preoperative period of aneurysm clamping. Aracaju, SE, Brazil, 2015

\begin{tabular}{|c|c|c|c|}
\hline \multirow[t]{2}{*}{ Variables } & \multicolumn{2}{|c|}{ Preoperative pain n(\%) } & \multirow[t]{2}{*}{$p$-value* } \\
\hline & Yes & No & \\
\hline \multicolumn{4}{|l|}{ Pain in the eye } \\
\hline Yes & $6(40)$ & $2(15)$ & 0.022 \\
\hline No & $9(60)$ & $11(85)$ & \\
\hline \multicolumn{4}{|c|}{ Visual symptom associated to pain } \\
\hline Yes & $4(27)$ & $2(15)$ & 0.065 \\
\hline No & $11(73)$ & $11(85)$ & \\
\hline \multicolumn{4}{|c|}{ Visual symptoms duration } \\
\hline More than $60 \mathrm{~min}$ & $1(7)$ & $1(8)$ & 0.79 \\
\hline Up to 7 days & $3(20)$ & $1(8)$ & \\
\hline Not applicable & $11(73)$ & $11(85)$ & \\
\hline
\end{tabular}

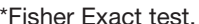

\section{DISCUSSION}

BA-induced headache leads to patient distress with negative repercussions in health recovery and rehabilitation process. For this reason, this pain deserves being systematically and broadly evaluated aiming at assuring better health team performance for the adequate management of this pain.

Historically, females are more concerned with health than males, so they look more often for health services and are submitted to a larger number of diagnostic and therapeutic procedures ${ }^{7}$. This might be the explanation for the predominance of females in our study.

Mean age was 47.6 years, with emphasis to age group above 45 years, which confirms other studies carried out with patients submitted to craniotomy ${ }^{8,9}$.

$\mathrm{AH}$ and $\mathrm{DM}$ were common among studied patients. This might have influenced headache frequency and intensity ${ }^{10}$. In addition, cardiovascular and metabolic diseases might contribute to poorer clinical diagnosis ${ }^{11}$. So, the health team should detect them early aiming at minimizing their noxious effects on patients' clinical recovery, such as postoperative intracranial hypertension and metabolic imbalances.

Although females look more often for health services ${ }^{7}$ and $\mathrm{AH}$ and DM require regular medical follow up, the demand for health services was caused by sudden factors, that is, persistent headache previous to hospitalization in many patients was not a reason for the early search for health professionals. Most part of the sample has chosen self-medication in moments of pain exacerbation. This is worrisome because when aneurysms are not early treated, there is risk of rupture, which negatively influences patients' health status.

The history of previous surgeries may trigger anxiety and, consequently, reflect in increased preoperative pain intensity ${ }^{12}$. Pain worsening brings several damages to patients, such as increased heart work, decreased blood offering to tissues and increased distress ${ }^{13}$, which may also be noxious for patients' clinical recovery.
Most patients had preoperative moderate, pulsing and frontal headache. Studies evaluating the prevalence of pain in patients submitted to craniotomy had high frequency of preoperative pain with similar characteristics ${ }^{8-14}$. The presence of aneurysm might have influenced pain pulsing character and frontal location.

Nausea and vomiting were symptoms referred by patients with pain. Prophylactic administration of antiemetics may decrease and/or prevent nausea and vomiting in patients submitted to craniotomy ${ }^{15}$. Adequate prevention and treatment of nausea and vomiting minimizes possible postoperative troubles such as bronchial aspiration, hydroelectrolyte imbalance and increased intracranial pressure. In addition, they decrease physical efforts and consequently pain.

Pain intensity may increase when patients perform simple activities such as standing up or walking ${ }^{9}$, with risk of early aneurysm rupture. In our study, physical effort and shaking of head were associated to pain worsening. So, the health team should orient patients to avoid sudden changes in position, as well as help them walking and performing daily activities.

Other factors associated to headache are neurosensory changes, such as pain in the eye. Similar study with patients submitted to aneurysm clamping has found relationship between headache, pain in the eye and visual symptoms ${ }^{10}$. In our study, visual changes had no significant association. It is possible that neurosensory changes are related to intracranial aneurysm location.

Simple analgesics, associated to NSAIDs and weak opioids, were more often prescribed. However such prescriptions had no fixed administration times. The use of analgesics in fixed time prevents major fluctuations of drug plasma level and peaks of pain. Multimodal analgesic therapy is emphasized not only for its effectiveness but for decreasing doses and, as a consequence, preventing adverse effects ${ }^{4}$. Prophylactic administration of analgesics in a systematic manner is critical to maintain patients' hemodynamic balance and to assure effective neurosurgical recovery.

It should be highlighted that pain control is patients' right which should be assured aiming at preventing noxious effects of pain, thus assuring adequate assistance ${ }^{13}$.

\section{CONCLUSION}

Headache in patients in the preoperative period of BA clamping is in general moderate, frontal and pulsing. Nausea and vomiting are often associated to pain, which worsens with physical effort and shaking of head. Pain in the eye may also be present in these patients. Analgesics were not systematically prescribed, being insufficient for total pain relief. Headache is common in patients in the preoperative period of aneurysm clamping, but its evaluation is still a challenge for the multiprofessional team. So, this study explains major items to be investigated and general headache characteristics of these patients. This helps improving the level of suspicion of health professionals with regard to the presence of brain 
aneurysms, which helps early diagnosis and faster improvement of neurological recovery.

\section{REFERENCES}

1. Wardlaw JM, White PM. The detection and management of unruptured intracranial aneurysms. Brain. 2000;123(Pt 2):205-21.

2. Zorowitz RD, Smout RJ, Gassaway JA, Horn SD. Usage of pain medications during stroke rehabilitation: the Post-Stroke Rehabilitation Outcomes Projects (PSROP). Top Stroke Rehabil. 2005;12(4):37-49.

3. Molnár L, Simon É, Nemes R, Fülesdi B, Molnár C. Postcraniotomy headache. J Anesth. 2014;28(1):102-11.

4. Schwedt TJ, Gereau RW, Frey K, Kharasch ED. Headache outcomes following treatment of unruptured intracranial aneurysms: a prospective analysis. Cephalalgia. 2011;31(10):1082-9.

5. Morris LMD. The International Classification of Headache Disorders, $3^{\text {rd }}$ ed. (ICHD III) - Changes and Challenges. Headache Currents--Clinical Review. 2013:1383-95.

6. Goren A, Gross HJ, Fujii RK, Pandey A, Mould-Quevedo J. Prevalence of pain awareness, treatment, and associated health outcomes across different conditions in Brazil. Rev Dor. 2012;13(4):308-19.

7. Ribeiro MC, Pereira CU, Sallum AM, Silva CB, Santos DS, Nunes MS, et al. Prevalência de dor no pós-operatório de craniotomia eletiva. Arq Bras Neurocir.
2012;31(3):124-7.

8. de Oliveira Ribeiro Mdo C, Pereira CU, Sallum AM, Martins-Filho PR, Santana JM, Silva Nunes M, et al. Immediate post-craniotomy headache. Cephalalgia. 2013;33(11):897-905.

9. Kim YD, Park JH, Yang SH, Kim S, Hong JT, Sung JH, et al. Pain assessment in brain tumor patients after elective craniotomy. Brain Tumor Res Treat. 2013;1(1):24-7.

10. Chang SI, Tsai MD, Wei CP. Posterior communicating aneurysm with oculomotor nerve palsy: clinical outcome after aneurysm clipping. Turk Neurosurg. 2014;24(2):170-3

11. Hanak BW, Walcott BP, Nahed BV, Muzikansky A, Mian MK, Kimberly WT, et al Postoperative intensive care unit requirements after elective craniotomy. World Neurosurg. 2014;81(1): 165-72.

12. Magalhães JE, Azevedo-filho HR, Rocha-Filho PA. The risk of headache attributed to surgical treatment of intracranial aneurysms: a cohort study. Headache. 2013;53(10):1613-23.

13. Ribeiro MC, Pereira CU, Sallum AM, Martins-Filho PR, Nunes MS, Carvalho MB. Dor pós-operatória em pacientes submetidos à craniotomia. Rev Dor. 2012;13(3):229-34.

14. de Gray LC, Matta BF. Acute and chronic following craniotomy: a review. Anaesthesia. 2005;60(7):693-704.

15. Ryu JH, Lee JE, Lim YJ, Hong DM, Park HP, Han JI, et al. A prospective, randomized, double-blind, and multicenter trial of prophylactic effects of ramosetronon postoperative nausea and vomiting (PONV) after craniotomy: comparison with ondansetron. BMC Anesthesiol. 2014;14(63):1-8 